\title{
Regulating The Pharmaceutical Industry In The European Union: A Dilemma Of Achieving A Single Market
}

Aysegul Timur, Hodges University, USA

Gabriel Picone, University of South Florida, USA

\begin{abstract}
Pharmaceutical pricing and reimbursement regulations create a dilemma to achieve a single pharmaceutical market in the European Union (EU). Although considerable progress has been made in the past years in harmonization of the pharmaceutical markets, the pricing decisions or systems have continued to be operated on a national basis, which results in price differences across the member states. These price differences create opportunity for parallel trade which, in combination with the EU single market principle calling for the free movement of goods, could lead to reduction in price differences. Among the harmonization efforts by the European Commission, national decisions on pricing and controls, plus parallel trade dilemma, we attempt to analyze the bilateral drug price differences using a sample of countries that represent from strict to relatively less pharmaceutical regulations. Almost all member countries regulate pharmaceutical prices, either directly or indirectly, in the EU, which creates less or more price differences despite market integration. This paper is simply aimed at analyzing price differences in the European pharmaceutical market, employing annual 1994-2003 IMS Health Data from five EU countries (Germany, the United Kingdom, France, Italy and Spain) on prices of molecules used to treat cardiovascular disease. The analysis includes a two step approach. First, we calculate the common use of Laspeyres and Paasche weighted price and quantity indices to make comparisons for both bilaterally matched molecules (considering Spain as the base country) and diffused molecules that are available for five countries. Second, we adopt a hedonic price regression to control observable quality and market characteristics and then re-analyze price differentials. The study concludes that price differences still exist, but are decreasing over time. Even though the results are sensitive to sample and methods used, we found implicit evidence that harmonization efforts by the European Commission may ease reducing price differences in the long run, but it should not be interpreted as moving toward complete elimination of price differences due to complexities in this industry.
\end{abstract}

\section{INTRODUCTION}

$\mathscr{J}$ he European-based pharmaceutical industry is important because it contributes to the economic, social and research life of the European Union. Pharmaceutical companies employ approximately 645,000 workers in Europe (2007), including around 100,000 people in research and development. The industry makes a significant contribution to the European Union's trade balance ( $€ 49$ billion in 2007), in addition to making a substantial investment in the European science base ( $€ 26$ billion in 2007). However, despite the strength of the industry for both production and development, Europe has not been able to maintain its leading role as a pharmaceutical industry. The recent statistics show that six of the top ten biggest selling medicines in the world originated in Europe and four in the USA in 1992, but these numbers had reversed with seven of the top selling medicines coming from the USA and only three from Europe in 2005 (European Commission April 2009).

The European Commission has aimed to achieve a single pharmaceutical market to make the industry again the natural home of pharmaceuticals. Completion of the single market in pharmaceuticals is essential for this 
purpose, and in addition to protect the health of patients, for rapid access to the market, to encourage innovation in therapies, and for a competitive environment. However, the single pharmaceutical market process has been distracted by the considerable fragmentation of the national markets with different pricing regulations and reimbursements, which lead to extra costs for the industry and patients.

Achieving a single market in pharmaceuticals is complicated not only by the diverse interest involved by each member country, but also by the unique nature of the research-based industry. The functions of demand are split between the patient, the prescribing doctor, different characteristics of health care systems and the consumers' expectation on affordable prices for medical progress. There are big differences between the national markets in pharmaceuticals, from the point of standard of living, demand and consumption of pharmaceutical to distribution costs, pricing and reimbursement regulations and health care systems. Particularly, regulating the pharmaceutical industry is a difficult challenge for policy makers, who seek low health care costs and affordable drugs, but also want accessibility to the highest quality medicines and more generally a successful industry (Permanand and Mossialos 2004). Despite the European Union (EU)-level movement toward the single pharmaceutical market and the European Commission's expanding role in this area, pharmaceutical policy is still primarily determined at the national level (Norris 1998). Pharmacoeconomics, parallel importing, and generic substitution also impact policy decisions (Seget 2003). Therefore, despite decades of Community level attempts at coordination, European pharmaceuticals remain separate national markets rather than a single market. Each member state uses a different system, adapted to its own economic and health needs. The Commission has never proposed legislative measures to address pharmaceutical price controls and reimbursement regulations at the EU level, considering this to be primarily a national concern. Even though the industry continues requesting that the Commission remove certain forms of national price regulation, the industry cannot be wholly protected from inter-brand competition from generics following patent expiration or intra-brand competition created by parallel importing from lower priced EU countries (Mossialos, et al. 2004). On the other hand, some national governments have been taking "me-too" approaches for regulating drug prices and controlling reimbursement (Redwood 1994), imitating policies of other governments despite the limited effectiveness and evaluation of many of the measures adopted (Guillen and Cabiedes 2003). Consequently, both industrial policy and regulation of the pharmaceuticals remain responsibilities shared between the EU level and the member states. The Commission has no power to determine national prices, reimbursement regulations or profit controls, but attempts to ensure that national procedures are efficient, transparent and fair. It stresses that there are no reasons to exempt pharmaceuticals from the single market rules (European Commission 1998).

In this paper, we take Spain as a base country, which represents a strictly regulated pharmaceutical industry and compare its prices with lesser extent regulated markets, such as France and Italy, and the least regulated markets, Germany and the United Kingdom. Therefore, we expect relatively lower prices in Spain than the other nations. We find that the prices are indeed low in Spain, but also observe that price differentials are getting closer over time.

\section{REGULATING EUROPEAN PHARMACEUTICAL PRICES AND REIMBURSEMENT}

The current EU national health care systems are diverse in both funding and delivery of health care. National governments have implemented many different measures, from controls and incentives to directly influence supply and demand or indirectly reduce expenditures, which in terms of overall health have grown faster than GNP in all European countries over the last 20 years (Ess, et al. 2003). To slow this growth, some countries have emphasized direct price controls and supply side cost containment regulations, while others have emphasized demand side financial incentives, quantity controls and physician educational initiatives (Kanavos 2001; Mossialos, et al. 2004).

Supply regulations and cost containment measures consist primarily of direct fixed price controls, profit (or rate of return) controls and reference pricing. Direct price controls include negotiated prices, price-caps (fixed maximum price), cost-plus prices, price comparison to other countries or similar products within the same country, price cuts or freezes or price-volume agreements. Almost all EU countries except Germany and the UK apply direct price controls to on-patent drugs. In the UK new patent drugs can be freely launched but the prices are indirectly controlled by the rate of return controls that ensure pharmaceuticals are not realizing excessive profits. The 
permitted rate of return on capital is around $17-21 \%$ (Ess, et al. 2003). France also introduced free pricing in 2003, but only for products defined as innovative by the National Transparency Commission with some limitations. In some countries such as France, Italy, Spain, Austria, and Portugal, prices are directly controlled through negotiations. In others, prices are fixed by national authorities according to a list of factors that depend on whether the main objective is to achieve the lowest possible price or a price that balances profitability with cost containment. Many countries have additionally applied cuts and freezes to the maximum fixed prices, often in an attempt to meet short-term budget constraints. In France, prices are set initially for 5 years. In most countries, price cuts have been the norm. Some countries, like Spain, reward companies that contribute to the economy or invest in research and development. In addition to using a cost-plus formula, Spain considers therapeutic value. Price comparisons are another common measure. However, there is concern about accuracy of the comparisons because of methodological difficulties and differences across countries in strength, formulation and pack sizes available (Mossialos, et al. 2004).

Another measure, reference pricing, has gained popularity over the years in places like Germany, Italy, France, and Spain. Reference pricing is "a system where the buying agent decides on a reimbursement price and then the user/patient or insurer pays the difference if the chosen medicine is more expensive" (Lopez-Casasnovas; Puig-Junoy 2000). Reference pricing aims to control pharmaceutical expenditures by defining a fixed amount to be paid by the government or other third party payer and can effectively eliminate price gaps between therapeutically similar products and improve market transparency by increasing patient and physician awareness of actual price levels (Dickson 1992). The latter can bring about switches to cheaper drugs that lead to price decrease for the more expensive version (Mossialos, et al. 2004), which encourages downward price convergence (Lopez-Casasnovas; Puig-Junoy 2000).

Current EU price control systems limit the returns to any added therapeutic value of the drug. Reimbursement levels reflect negotiations between the pharmaceutical company (a monopolist with respect to a new drug) and the government or insurer (a monopsonist). A number of countries have started to incorporate further economic evaluations into the decision-making process, either as an additional tool to determine the reimbursement price (e.g. Finland) or as a mechanism to guide prescribers (e.g. the UK National Institute of Clinical Excellence). However, there has been little consistency in EU reimbursement regulations.

There are also several key elements of demand-side policies in member states. One is to influence the doctors who prescribe medicines for patients (Caves, et al. 1991). This can be done through positive and negative lists, issuing guidelines to which medications can be prescribed for certain conditions, and monitoring prescribing practices (doctors act as a "gatekeeper"). Additionally, budgets are imposed to force doctors to take costs into consideration when selecting between alternative treatments (e.g. individual doctor or group practice budgets in the UK, budgets for all doctors in a region in Germany). The second key element is restrictive lists that all member states operate in various ways. Regulatory approval that is necessary before a drug can be marketed does not imply that the drug will be covered by the health care system; in principle, drugs that are less effective or more expensive than substitutes should not be reimbursed. These lists operate in three different ways. In some countries, the drug must be on the "positive list" to be reimbursed, while inclusion on the "negative list" implies no government reimbursement. In others, only one list is used. In positive list counties, the drug must be on the list to be reimbursed. In negative list countries, only drugs on the negative list are not reimbursable.

Some countries (e.g. France) have been altering the system of paying physicians, moving from a fee-forservice and access to any physician/specialist regime to more restrictive gatekeeper systems. An alternative way to regulate demand is regulating what products pharmacists can sell, who may sell prescription medicines, what they can dispense, how prescriptions are written and substitution procedures (Kanavos 2001). Another option is patient cost-sharing through paying some combination of a proportion of the total price, a fixed charge per prescription, and an annual deductible (Noyce, et al. 2000). For example, in Spain co-payments are $40 \%$ of the sales price, while in France the majority of the population pays less than $5 \%$ of retail prices out of pocket.

Finally, the size of the generic market has grown recently in several EU countries. For example, in the UK, the use of generic drugs has increased from 16\% of prescriptions in 1977 to 54\% in 1994 (Ess, et al. 2003). The two EU approaches to regulating generic drug prices are limiting the generic price to a fixed percent less than the 
originator product or the cheapest generic equivalent, and to apply a reference price scheme (Mossialos, et al. 2004). In some countries (e.g. Germany), generic substitution has been a successful short-term cost containment policy (Ess, et al. 2003).

Spain has both supply and demand side regulations. Table 1 shows a summary of national controls on pharmaceuticals from 1999 through 2002 (Kanavos 2001; 2002). It is expected that under strict regulations, prices are much lower in Spain than other sample countries.

Table 1: National Controls on Pharmaceuticals in Spain

\begin{tabular}{|c|c|c|c|c|c|c|c|}
\hline \multicolumn{8}{|c|}{ Pharmaceutical Supply (Pricing and Reimbursement) in Spain } \\
\hline \multicolumn{4}{|c|}{1999} & \multicolumn{4}{|c|}{2002} \\
\hline \multicolumn{2}{|c|}{ Pricing } & \multicolumn{2}{|c|}{ Reimbursement } & & Pricing & & Reimbursement \\
\hline \multicolumn{2}{|c|}{$\begin{array}{l}\text { a. Price Control through } \\
\text { negotiation on a cost-plus } \\
\text { basis } \\
\text { b. International price } \\
\text { comparisons } \\
\text { c. Price-volume agreement for } \\
\text { expensive products } \\
\text { d. Pact stability agreement with } \\
\text { government also promoting } \\
\text { R\&D. } \\
\text { e. Price cuts } \\
\text { f. Payback clause if drug } \\
\text { spending increases beyond an } \\
\text { agreed limit }\end{array}$} & \multicolumn{2}{|c|}{$\begin{array}{l}\text { a. Positive list } \\
\text { b. Negative list } \\
\text { c. Reference pricing } \\
\text { for estimating } \\
\text { maximum } \\
\text { reimbursement for } \\
\text { multisource } \\
\text { products }\end{array}$} & \multicolumn{2}{|c|}{$\begin{array}{l}\text { a. Price control through negotiation } \\
\text { on a cost-plus basis, taking into } \\
\text { account expected sales and } \\
\text { allowing specific margins for } \\
\text { profits (12-18\% of allowable } \\
\text { cost), advertising (12-16\% of } \\
\text { allowable costs) and R\&D } \\
\text { conducted in Spain. } \\
\text { b. International price comparisons } \\
\text { for active ingredient when } \\
\text { difficulties arise in assessing the } \\
\text { transfer price of a molecule } \\
\text { c. Price volume agreement for } \\
\text { expensive products } \\
\text { d. Pact stability agreement with } \\
\text { government also promoting R\&D } \\
\text { e. Further price cuts } \\
\text { f. Payback clause intensified. }\end{array}$} & \multicolumn{2}{|c|}{$\begin{array}{l}\text { a. Positive list } \\
\text { b. Negative list } \\
\text { c. National reference } \\
\text { pricing } \\
\text { d. Andalucia } \\
\text { reference pricing }\end{array}$} \\
\hline \multicolumn{8}{|c|}{ Prescribing, Dispensing and Consumption of Pharmaceuticals, 2002} \\
\hline $\begin{array}{c}\text { Positive } \\
\text { List }\end{array}$ & Negative List & $\begin{array}{l}\text { Guidelines/ } \\
\text { Monitoring }\end{array}$ & $\begin{array}{r}\text { GeI } \\
\text { Presc }\end{array}$ & & Substitution & & Co-Payment \\
\hline Yes & Yes & Yes & Some & & $\begin{array}{l}\text { With doctor's agreement and } \\
\text { part of reference pricing }\end{array}$ & & $\begin{array}{l}\% \text { up to a max per } \\
\text { item }\end{array}$ \\
\hline
\end{tabular}

Source: (Kanavos 2002)

\section{DATA AND METHODOLOGY}

We follow the approach by Danzon and Chao (2000a), therefore, the drug is defined by active ingredient, i.e. molecule (MOL) and Anatomic Therapeutic Category (ATC) without regard to manufacturer and brand name. The data come from IMS Health, where the Standard Unit (SU) is defined a single dose as one tablet or capsule, five milliliters of a liquid (i.e. one teaspoon), or one ampoule or vial of an injectable product (IMS 2002; 2005). Therefore, a country's standard unit (SU) price for a MOL/ATC is its volume-weighted average price per dose over all presentations, including generics, licensed, OTC, and parallel imported products (Danzon and Furukawa 2003). Multiple molecule drugs are excluded because the relative mix of active ingredients varies across countries. With the employment of this measurement unit, it is assumed to avoid sample selection bias and measurement error.

This study is limited to retail sales of drugs for cardiovascular disease (CVD), which is among the top three causes of death in OECD countries. We sample the eight three-digit CVD categories, studied by Dickson and Jacobzone (2003). These categories cover a wide range of both newer and older innovations that form the core of pharmacotherapy for CVD. The five countries in the sample are Germany, the UK, Italy, Spain, and France. These countries have the largest pharmaceutical production and sales in the EU-15 (OECD 2003) and represent the five largest pharmaceutical markets in the world after the US and Japan (Pammolli, et al. 2004). 
Index calculations are based on bilateral matches (to Spain) across countries for each year. The match rate varies depending on the benchmark country. The most common price indices, both generally and in this literature, are the Laspeyres and Paasche indices (Berndt, et al. 2002; Berndt, et al. 1996; Berndt, et al. 1993; Danzon and Chao 2000a; Gilles 1940). The Laspeyres price index, for example, is a weighted average of individual molecule price changes, with the weights equaling the expenditure share for each good in the base period. It compares the price of a base period basket of goods with the price of the same basket in the current period. In contrast, the Paasche price index compares the price of a current basket of goods with the price of the same basket in the base period: Because prices are weighted by current period quantities (and vice versa for the quantity index), the weights change for each period in which a Paasche index is calculated (Allen 1975). Additionally, because Laspeyres uses base weights while Paasche uses current weights, the two indexes are generally different even for the same period, but usually are similar when the periods being compared are not too far apart (as in this study). The Paasche price index tends to be lower than the Laspeyres when prices are increasing and higher when prices are decreasing.

A similar index calculation data set (for diffused molecules) is also constructed based on matches for all five countries for each year. In our data, there are 38 diffused molecules, which are available for five countries. Quasi-hedonic price regressions are based on a sample set that includes 658 molecules (119 for France, 177 for Germany, 135 for Italy, 119 for Spain and 108 for the UK) for the 1994-2003 period.

Since drugs come in different forms, pack sizes, and strength levels in different countries, hedonic regression is employed to explain the price of a good in terms of these characteristics. Therefore, hedonic price regressions estimate the value of observed characteristics of the drugs/molecules. Drug characteristics and prices also differ across countries because of their regulatory and reimbursement environments.

The specification of the model is,

$\ln P_{k, j, t}=\beta X_{k, j, t}+\gamma_{t}+\delta_{j}+\theta_{j, t}+c_{k}+u_{k, j, t}$

adopted from Danzon and Chao (2000a), where $\ln P_{k, j, t}$ is the log price per SU for molecule k in country jand year t, $X$ is a vector of quality and market characteristics for that molecule, country and year $\mathrm{t}, \gamma_{\mathrm{t}}$ is year indicators, $\delta_{\mathrm{j}}$ is country indicators, $\theta_{j, t}$ is an interactions between indicators for country $\mathrm{j}$ and year $\mathrm{t}, c_{k}$ is an indicator for molecule k, and $u_{k, j, t}$ is the remaining error. The main goals of this regression are to obtain consistent estimates of $\theta_{j, t}$, which reflects the pattern of bilateral country price differences over time when the molecule and observable quality and market characteristics are held constant, and $u_{k, j, t}$, which represents cross country price differences that cannot be explained by observable drug characteristics, specific molecules available and average year-specific price differences.

This model is estimated using panel data methods that account for time- and country-invariant unobserved heterogeneity associated with each specific molecule. Both fixed and random effect models are estimated. These vary according to their treatment of the unobserved molecule-specific effect $c_{k}$, which is called a "random effect" when treated as a random variable and a "fixed effect" when treated as a parameter to be estimated for each molecule. Both models require zero conditional mean to hold, i.e. $\mathrm{E}\left(u_{k, j, t} \mid X_{k, j}, c_{k}\right)=0$, in order to generate consistent parameter estimates. Because the random effect model implicitly places $c_{k}$ in the error term, for consistency it further requires zero correlation between the observed explanatory variables and the unobserved effect, i.e. $\operatorname{Cov}\left(X_{k, j, t}, c_{k}\right)=0$. In contrast, the fixed effect model allows arbitrary correlation between $c_{k}$ and $X_{k, j, t}$. The fixed effect model is therefore more robust than the random effect model. Lastly, the Hausman (1978) test is used to check a more efficient model against a less efficient but consistent model to make sure that the more efficient model gives consistent results. The Hausman test tests the null hypothesis that the coefficient estimated by the efficient random effects estimator are the same as the ones estimated by the consistent fixed effect estimator. If they are, then it is safe to use random effects. If not, the fixed effect must be used.

The dependent variable is SUPrice, which represents the average price per standard unit (SU) for each ATC/molecule, defined as the volume-weighted average retail price over all forms and packs. Local currency prices are converted to euros by IMS Health using constant exchange rates, which minimize effects of exchange rate fluctuations. Molecule Age is the number of years since the first product launch of molecule k in country j, and is 
the same for all products in a molecule. Strength $(g)$ is the mean grams of active ingredient per standard unit, averaged over all packs. Form Code represents the number of different formulations of the products in each molecule, and is included as a measure of the choice and convenience available to patients. Forms include different types of tablets (e.g. film, chewable, gel), capsules, ampoules, powders, drops, syrups, syringes, and liquids, along with different strengths and pack sizes. Pack Size is the average number of standard units over all packs in a molecule. Pack sizes were converted to IMS standard units. Diffused Molecules is the number of sample countries (i.e. between 0 and 5) in which the molecule is available, as a measure of therapeutic value. Generic Competitors is the number of manufacturers of the products in the molecule, including originators, licensees, parallel imports and generics. Therapeutic Substitute Molecules is the number of therapeutic competitors that are chemically distinct but used to treat the same indication, i.e. the number of molecules in the ATC3.

\section{FINDINGS}

Table 2 and Table 3 report the estimated Laspeyres and Paasche price and quantity indexes, as Spain represents the benchmark country. The standard unit is the volume measure and the fixed euro is the monetary measure. The Laspeyres index uses benchmark country weights, whereas the Paasche index uses own country weights. The indices are measured for both bilateral matched molecules and diffused molecules.

Table 2 shows that in 1994 Laspeyres prices are higher by 33\% in the UK, 39\% in Germany, 38\% in France and $47 \%$ in Italy. These price differences decrease in 2003 for all sample countries to only $10 \%$ in Germany, 45\% in France, 24\% in the UK and 31\% in Italy, relative to Spain. The Paasche index generally shows smaller price differentials. In 1994 prices are higher by $32 \%$ in Italy, $47 \%$ in the UK, 28\% in France and $38 \%$ in Germany. In 2003, price differentials are getting closer by 0\% in Germany, 20\% in Italy, 37\% in France, and 23\% in the United Kingdom. Thus, both the magnitude and rank ordering of the price differentials depend on which weights are used. As a matter of fact, all these sample countries have indeed higher prices than Spain for the entire time period of the analysis.

The Laspeyres and Paasche quantity indices show more consumption than in Spain for all countries. The results reveal large cross-national differences in per capita drug consumption.

The price indices for diffused molecules relative to Spain (Table 3) generally show similar but some cases smaller price differences between countries than the indices based on the larger bilaterally matched samples. This could possibly reflect particularly increasing parallel trade and employing the international price comparison regulatory method.

Table 4 shows the results of the quasi-hedonic price regressions estimated by both fixed and random effect models, with Germany as the base country. The Hausman test rejects the null hypothesis, so the fixed effect estimator is presumed consistent and hence, used to interpret the price differentials for all the molecules.

Most of the quality and market variables have the expected sign and are statistically significant, but their effects are small in magnitude. Standard unit price is expected to increase in strength but it is insignificant. The number of forms available is expected to be positively related in markets, if range of formulation enhances effectiveness, convenience and value. Additionally, introducing a new formation is a method of obtaining a price increase in countries that do not permit price increases for established products or when the product life cycle declines. Here, form code is inversely related due to possible explanations of therapeutic category-specific differences in medical norms and insurance. SU price is expected to inversely relate to molecule age, suggesting that newer molecules offer improved therapeutic quality, although molecule age may also reflect life-cycle regulatory effects, but it is not significant. Price decreases with pack size, consistent with economies of scale in packaging, and diffused molecules, which is a proxy for diffused therapeutic value. Generic competition lowers price as it is expected but not significant. Therapeutic substitute molecule is expected to be inversely related to price due to substitution effect but here again, it is directly related to the price. When a new molecule is introduced, assuming better therapeutic treatment, a few good substitutes will be available and the drugs with the new main ingredient will have high prices. But after time, competition eliminates some of the substitutes while at the same time lowers prices. 
Table 2: Pharmaceutical Price and Quantity Indexes for All Molecules, Relative to Spain

\begin{tabular}{|c|c|c|c|c|c|c|c|c|c|c|c|c|}
\hline \multirow{2}{*}{ Index Measures } & \multicolumn{4}{|c|}{1994} & \multicolumn{4}{|c|}{1995} & \multicolumn{4}{|c|}{1996} \\
\hline & GR & FR & UK & ITY & GR & FR & UK & ITY & GR & FR & UK & ITY \\
\hline Number of ATC/Molecule Matching & 81 & 63 & 71 & 82 & 78 & 62 & 67 & 78 & 78 & 65 & 68 & 79 \\
\hline Laspeyres Price Index (SPN weighted) & 1.3851 & 1.3798 & 1.3284 & 1.4659 & 1.3104 & 1.3779 & 1.3303 & 1.3032 & 1.2570 & 1.3663 & 1.3253 & 1.3245 \\
\hline Paasche Price Index (Own weighted) & 1.3797 & 1.2787 & 1.4740 & 1.3244 & 1.2941 & 1.2517 & 1.4795 & 1.1753 & 1.2323 & 1.2400 & 1.4615 & 1.2126 \\
\hline Laspeyres Quantity Index & 2.3118 & 1.1846 & 2.5719 & 1.4422 & 2.3050 & 1.2043 & 2.3777 & 1.4065 & 2.3753 & 1.2605 & 2.2487 & 1.3634 \\
\hline Paasche Quantity Index & 2.3029 & 1.0979 & 2.8538 & 1.3030 & 2.2764 & 1.0940 & 2.6444 & 1.2684 & 2.3287 & 1.1439 & 2.4797 & 1.2482 \\
\hline
\end{tabular}

\begin{tabular}{|c|c|c|c|c|c|c|c|c|c|c|c|c|}
\hline \multirow{2}{*}{ Index Measures } & \multicolumn{4}{|c|}{1997} & \multicolumn{4}{|c|}{1998} & \multicolumn{4}{|c|}{1999} \\
\hline & GR & FR & UK & ITY & GR & FR & UK & ITY & GR & FR & UK & ITY \\
\hline Number of ATC/Molecule Matching & 77 & 65 & 68 & 74 & 78 & 69 & 68 & 75 & 77 & 66 & 66 & 73 \\
\hline Laspeyres Price Index (SPN weighted) & 1.1929 & 1.3553 & 1.3137 & 1.3165 & 1.1559 & 1.3937 & 1.2885 & 1.2978 & 1.1565 & 1.4089 & 1.2701 & 1.3178 \\
\hline Paasche Price Index (Own weighted) & 1.1423 & 1.2391 & 1.4314 & 1.2074 & 1.0924 & 1.2606 & 1.3847 & 1.2032 & 1.0748 & 1.3154 & 1.3463 & 1.2239 \\
\hline Laspeyres Quantity Index & 2.3843 & 1.2934 & 2.1498 & 1.2633 & 2.3024 & 1.3120 & 2.0025 & 1.2147 & 2.2541 & 1.3322 & 1.9368 & 1.2151 \\
\hline Paasche Quantity Index & 2.2831 & 1.1825 & 2.3424 & 1.1586 & 2.1758 & 1.1867 & 2.1520 & 1.1261 & 2.0949 & 1.2438 & 2.0531 & 1.1285 \\
\hline
\end{tabular}

\begin{tabular}{|c|c|c|c|c|c|c|c|c|c|c|c|c|}
\hline \multirow{2}{*}{ Index Measures } & \multicolumn{4}{|c|}{2000} & \multicolumn{4}{|c|}{2001} & \multicolumn{4}{|c|}{2002} \\
\hline & GR & FR & UK & ITY & GR & FR & UK & ITY & GR & FR & UK & ITY \\
\hline Number of ATC/Molecule Matching & 78 & 65 & 64 & 72 & 76 & 63 & 65 & 70 & 74 & 63 & 62 & 69 \\
\hline Laspeyres Price Index (SPN weighted) & 1.1759 & 1.4349 & 1.2938 & 1.3770 & 1.2274 & 1.4384 & 1.2964 & 1.3824 & 1.1980 & 1.4492 & 1.2680 & 1.3870 \\
\hline Paasche Price Index (Own weighted) & 1.0767 & 1.3567 & 1.3402 & 1.2773 & 1.1141 & 1.3513 & 1.3029 & 1.2768 & 1.0671 & 1.3633 & 1.2643 & 1.2938 \\
\hline Laspeyres Quantity Index & 2.2703 & 1.3576 & 1.9679 & 1.2270 & 2.3042 & 1.4704 & 1.9692 & 1.2806 & 2.3495 & 1.5478 & 1.8747 & 1.2126 \\
\hline Paasche Quantity Index & 2.0787 & 1.2836 & 2.0385 & 1.1382 & 2.0916 & 1.3814 & 1.9789 & 1.1827 & 2.0927 & 1.4560 & 1.8693 & 1.1312 \\
\hline
\end{tabular}

\begin{tabular}{|l|c|c|c|c|}
\hline \multirow{2}{*}{ Index Measures } & \multicolumn{4}{|c|}{$\mathbf{2 0 0 3}$} \\
\cline { 2 - 5 } & GR & FR & UK & ITY \\
\hline Number of ATC/Molecule Matching & 72 & 61 & 61 & 71 \\
\hline Laspeyres Price Index (SPN weighted) & 1.0989 & 1.4487 & 1.2392 & 1.3054 \\
\hline Paasche Price Index (Own weighted) & 0.9975 & 1.3730 & 1.2339 & 1.1987 \\
\hline Laspeyres Quantity Index & 2.4817 & 1.6173 & 1.8352 & 1.2398 \\
\hline Paasche Quantity Index & 2.2528 & 1.5328 & 1.8275 & 1.1384 \\
\hline
\end{tabular}


Table 3: Pharmaceutical Price and Quantity Indexes for Diffused Molecules, Relative to Spain

\begin{tabular}{|c|c|c|c|c|c|c|c|c|c|c|c|c|}
\hline \multirow{2}{*}{ Index Measures } & \multicolumn{4}{|c|}{1994} & \multicolumn{4}{|c|}{1995} & \multicolumn{4}{|c|}{1996} \\
\hline & GR & UK & FR & ITY & GR & UK & FR & ITY & GR & UK & FR & ITY \\
\hline Number of ATC/Molecule Matching & 38 & 38 & 38 & 38 & 38 & 38 & 38 & 38 & 38 & 38 & 38 & 38 \\
\hline Laspeyres Price Index (SPN weighted) & 1.2340 & 1.3125 & 1.2547 & 1.2163 & 1.1609 & 1.3057 & 1.2838 & 1.0890 & 1.1102 & 1.3025 & 1.2958 & 1.1345 \\
\hline Paasche Price Index (Own weighted) & 1.2961 & 1.2632 & 1.3138 & 1.2831 & 1.2111 & 1.2342 & 1.3294 & 1.1414 & 1.1427 & 1.2224 & 1.3255 & 1.1800 \\
\hline Laspeyres Quantity Index & 2.3180 & 1.3020 & 2.3520 & 1.4253 & 2.3544 & 1.3519 & 2.2150 & 1.4134 & 2.4347 & 1.4448 & 2.0988 & 1.3784 \\
\hline Paasche Quantity Index & 2.4345 & 1.2531 & 2.4627 & 1.5036 & 2.4561 & 1.2779 & 2.2937 & 1.4814 & 2.5060 & 1.3559 & 2.1468 & 1.4337 \\
\hline
\end{tabular}

\begin{tabular}{|c|c|c|c|c|c|c|c|c|c|c|c|c|}
\hline \multirow{2}{*}{ Index Measures } & \multicolumn{4}{|c|}{1997} & \multicolumn{4}{|c|}{1998} & \multicolumn{4}{|c|}{1999} \\
\hline & GR & UK & FR & ITY & GR & UK & FR & ITY & GR & UK & FR & ITY \\
\hline Number of ATC/Molecule Matching & 38 & 38 & 38 & 38 & 38 & 38 & 38 & 38 & 38 & 38 & 38 & 38 \\
\hline Laspeyres Price Index (SPN weighted) & 1.0546 & 1.2847 & 1.2949 & 1.1479 & 1.0275 & 1.3251 & 1.2857 & 1.1662 & 1.0300 & 1.3596 & 1.2707 & 1.2059 \\
\hline Paasche Price Index (Own weighted) & 1.0562 & 1.2171 & 1.3064 & 1.1724 & 1.0209 & 1.2331 & 1.2730 & 1.1778 & 1.0060 & 1.2802 & 1.2474 & 1.2099 \\
\hline Laspeyres Quantity Index & 2.3727 & 1.4794 & 2.0031 & 1.2827 & 2.2814 & 1.5418 & 1.9653 & 1.2414 & 2.2590 & 1.5841 & 1.8558 & 1.2458 \\
\hline Paasche Quantity Index & 2.3762 & 1.4015 & 2.0208 & 1.3101 & 2.2667 & 1.4347 & 1.9459 & 1.2537 & 2.2064 & 1.4916 & 1.8218 & 1.2500 \\
\hline
\end{tabular}

\begin{tabular}{|c|c|c|c|c|c|c|c|c|c|c|c|c|}
\hline \multirow{2}{*}{ Index Measures } & \multicolumn{4}{|c|}{2000} & \multicolumn{4}{|c|}{2001} & \multicolumn{4}{|c|}{2002} \\
\hline & GR & UK & FR & ITY & GR & UK & FR & ITY & GR & UK & FR & ITY \\
\hline Number of ATC/Molecule Matching & 38 & 38 & 38 & 38 & 38 & 38 & 38 & 38 & 38 & 38 & 38 & 38 \\
\hline Laspeyres Price Index (SPN weighted) & 1.0231 & 1.3745 & 1.2870 & 1.2717 & 1.0922 & 1.3833 & 1.3311 & 1.3591 & 1.0643 & 1.4404 & 1.3229 & 1.3533 \\
\hline Paasche Price Index (Own weighted) & 0.9884 & 1.3077 & 1.2444 & 1.2639 & 1.0380 & 1.2974 & 1.2440 & 1.3193 & 0.9909 & 1.3461 & 1.2277 & 1.3147 \\
\hline Laspeyres Quantity Index & 2.2897 & 1.5810 & 1.8399 & 1.2399 & 2.3449 & 1.7193 & 1.8959 & 1.2854 & 2.4456 & 1.7984 & 1.8710 & 1.2391 \\
\hline Paasche Quantity Index & 2.2120 & 1.5041 & 1.7790 & 1.2323 & 2.2286 & 1.6126 & 1.7719 & 1.2477 & 2.2771 & 1.6806 & 1.7363 & 1.2038 \\
\hline
\end{tabular}

\begin{tabular}{|l|c|c|c|c|}
\hline \multirow{2}{*}{ Index Measures } & \multicolumn{4}{|c|}{$\mathbf{2 0 0 3}$} \\
\cline { 2 - 5 } & GR & UK & FR & ITY \\
\hline Number of ATC/Molecule Matching & 38 & 38 & 38 & 38 \\
\hline Laspeyres Price Index (SPN weighted) & 0.9443 & 1.4832 & 1.3183 & 1.3119 \\
\hline Paasche Price Index (Own weighted) & 0.9107 & 1.3923 & 1.2291 & 1.2507 \\
\hline Laspeyres Quantity Index & 2.7505 & 1.8956 & 1.8777 & 1.2621 \\
\hline Paasche Quantity Index & 2.6528 & 1.7794 & 1.7506 & 1.2032 \\
\hline
\end{tabular}


Table 4: Hedonic Price Regression Results for All Molecules, Relative to Spain

\begin{tabular}{|c|c|c|}
\hline $\begin{array}{l}\text { Dependent variable: } \operatorname{logSUPrice} \\
\mathrm{N}=5481\end{array}$ & $\begin{array}{l}\text { Fixed Effect } \\
\text { Model }\end{array}$ & $\begin{array}{l}\text { Random Effect } \\
\text { Model }\end{array}$ \\
\hline Explanatory Variables & $\begin{array}{l}\text { Coefficient } \\
\text { (Standard Error) }^{1}\end{array}$ & $\begin{array}{l}\text { Coefficient } \\
\text { (Standard Error) }\end{array}$ \\
\hline \multicolumn{3}{|l|}{ Quality Characteristics } \\
\hline STRENGTHG & $\begin{array}{c}0.0691 \\
(0.0603)\end{array}$ & $\begin{array}{l}0.0668^{*} \\
(0.0179)\end{array}$ \\
\hline MOLECULE AGE & $\begin{array}{c}0.0017 \\
(0.0049)\end{array}$ & $\begin{array}{l}-0.0009 \\
(0.0014)\end{array}$ \\
\hline PACK SIZE & $\begin{array}{l}-0.0025^{*} \\
(0.0003)\end{array}$ & $\begin{array}{c}-0.0025^{*} \\
(0.0001)\end{array}$ \\
\hline FORM CODE & $\begin{array}{l}-0.0073^{*} \\
(0.0025) \\
\end{array}$ & $\begin{array}{c}-0.0072^{*} \\
(0.0009) \\
\end{array}$ \\
\hline DIFFUSED MOLECULES & $\begin{array}{l}-0.0882^{*} \\
(0.0339)\end{array}$ & $\begin{array}{l}-0.0573^{*} \\
(0.0161)\end{array}$ \\
\hline \multicolumn{3}{|l|}{ Market (Competition Characteristics) } \\
\hline GENERIC COMPETITORS & $\begin{array}{l}-0.0041 \\
(0.0042)\end{array}$ & $\begin{array}{c}-0.0040^{* *} \\
(0.0016)\end{array}$ \\
\hline THERAPEUTIC SUBSTITUTE MOLECULES & $\begin{array}{l}0.0111^{*} \\
(0.0053)\end{array}$ & $\begin{array}{l}0.0106^{*} \\
(0.0017) \\
\end{array}$ \\
\hline Country dummies (Prob>F) & 0.0000 & 0.0000 \\
\hline Time dummies $($ Prob $>F)$ & 0.0160 & 0.0965 \\
\hline Country/Time dummies $($ Prob $>F)$ & 0.0000 & 0.5288 \\
\hline$R^{2}$ (Within) & 0.2882 & 0.2869 \\
\hline Prob>F & 0.0000 & 0.0000 \\
\hline
\end{tabular}

Table 5: Quality Adjusted Standard Unit Price Differentials (\%) for All Molecules, Relative to Spain ${ }^{2}$

\begin{tabular}{|c|c|c|c|c|c|}
\hline Year & Spain & France & Italy & $\begin{array}{c}\text { United } \\
\text { Kingdom }\end{array}$ & Germany \\
\hline 1994 & - & 38.8 & 33.9 & 102.3 & 142.4 \\
\hline 1995 & 5.34 & 39.8 & 22.5 & 94.9 & 123.9 \\
\hline 1996 & 5.13 & 42.6 & 30.8 & 92.8 & 126.9 \\
\hline 1997 & 7.94 & 41.1 & 31.4 & 85.9 & 117.2 \\
\hline 1998 & 9.99 & 41.0 & 32.4 & 106.5 & 112.4 \\
\hline 1999 & 12.73 & 39.6 & 31.6 & 107.3 & 108.0 \\
\hline 2000 & 11.26 & 43.8 & 37.6 & 106.4 & 115.2 \\
\hline 2001 & 12.25 & 38.5 & 38.9 & 97.8 & 112.2 \\
\hline 2002 & 12.92 & 37.8 & 40.7 & 94.6 & 102.8 \\
\hline
\end{tabular}

\footnotetext{
${ }^{1}$ Standard errors are heteroskedasticity-robust. Standard errors adjusted for clusters in id. *, ** and $* * *$ reflect $\mathrm{p}<0.01, \mathrm{p}<0.05$ and $\mathrm{p}<0.10$.

${ }^{2}$ These are the coefficients of the country/time effects $\left(\theta_{\mathrm{j}, \mathrm{t}}\right)$ in the fixed effect quasi-hedonic regression model. Percentages are calculated as $100[\operatorname{Exp}(\theta)-1]$.
} 
Table 6: Hedonic Price Regression Results for Diffused Molecules, Relative to Spain

\begin{tabular}{|c|c|c|}
\hline $\begin{array}{c}\text { Dependent variable: logSUPrice } \\
N=1900\end{array}$ & $\begin{array}{c}\text { Fixed Effect } \\
\text { Model }\end{array}$ & $\begin{array}{c}\text { Random Effect } \\
\text { Model }\end{array}$ \\
\hline Explanatory Variables & $\begin{array}{c}\text { Coefficient } \\
{\text { (Standard Error })^{3}}^{-1}\end{array}$ & $\begin{array}{c}\text { Coefficient } \\
\text { (Standard Error) } \\
\end{array}$ \\
\hline \multicolumn{3}{|l|}{ Quality Characteristics } \\
\hline STRENGTHG & $\begin{array}{c}-0.1975^{\text {**** }} \\
(0.1081)\end{array}$ & $\begin{array}{l}-0.1422^{*} \\
(0.0507)\end{array}$ \\
\hline MOLECULE AGE & $\begin{array}{l}-0.0104 \\
(0.0145)\end{array}$ & $\begin{array}{l}-0.0217^{*} \\
(0.0034)\end{array}$ \\
\hline PACK SIZE & $\begin{array}{l}-0.0019^{*} \\
(0.0002)\end{array}$ & $\begin{array}{l}-0.0019^{*} \\
(0.0001)\end{array}$ \\
\hline FORM CODE & $\begin{array}{l}-0.0056^{\text {**** }} \\
(0.0029)\end{array}$ & $\begin{array}{l}-0.0057^{*} \\
(0.0009)\end{array}$ \\
\hline \multicolumn{3}{|l|}{ Market (Competition) Characteristics } \\
\hline GENERIC COMPETITORS & $\begin{array}{l}-0.0028 \\
(0.0048) \\
\end{array}$ & $\begin{array}{l}-0.0024 \\
(0.0016) \\
\end{array}$ \\
\hline THERAPEUTIC SUBSTITUTE MOLECULES & $\begin{array}{c}0.0094 \\
(0.0059)\end{array}$ & $\begin{array}{l}0.0092^{*} \\
(0.0022)\end{array}$ \\
\hline Country dummies (Prob $>F)$ & 0.0000 & 0.0000 \\
\hline Time dummies $($ Prob $>F)$ & 0.0000 & 0.0039 \\
\hline Country/Time dummies $($ Prob $>F)$ & 0.0000 & 0.8301 \\
\hline$R^{2}$ (Within) & 0.2593 & 0.2538 \\
\hline Prob $>F$ & 0.0000 & 0.0000 \\
\hline
\end{tabular}

Table 7: Quality Adjusted Standard Unit Price Differentials (\%) for Diffused Molecules, Relative to Spain ${ }^{4}$

\begin{tabular}{|c|c|c|c|c|c|}
\hline \multirow{2}{*}{ Year } & Spain & France & Italy & $\begin{array}{c}\text { United } \\
\text { Kingdom }\end{array}$ & Germany \\
\hline 1994 & - & 32.92 & 21.91 & 82.96 & 107.53 \\
\hline 1995 & 3.97 & 37.67 & 13.26 & 78.67 & 102.98 \\
\hline 1996 & 8.17 & 38.76 & 18.55 & 75.16 & 99.26 \\
\hline 1997 & 14.17 & 35.30 & 17.83 & 65.15 & 85.78 \\
\hline 1998 & 18.79 & 31.83 & 19.11 & 69.14 & 79.21 \\
\hline 1999 & 24.01 & 28.05 & 21.68 & 68.11 & 74.82 \\
\hline 2000 & 25.91 & 28.95 & 24.75 & 63.24 & 71.63 \\
\hline 2001 & 27.41 & 30.21 & 28.32 & 57.94 & 71.68 \\
\hline 2002 & 29.54 & 30.33 & 28.52 & 53.90 & 61.45 \\
\hline
\end{tabular}

The interest in these regressions is the coefficients of the country/year interactions, which trace out the pattern of price differences over time controlling for quality and market characteristics and molecule identity. The individual country dummy coefficients give the 1994 price differential between country and Germany, while the individual year dummy coefficients give the price differential for Germany between each year and 1994. Table 5 and Figure 1 show the price differences in percentages, estimated with the fixed effect model, relative to Germany in 1994 (the omitted country/year combination). The main result is that price differences are still significant, but the percentage differences are consistent with the expectations that price differentials are decreasing over time. All the countries have higher prices relative to Spain. Prices in France and Italy move similarly as well as Germany and the UK, which is likely attributable to their pharmaceutical industries having similar characteristics.

\footnotetext{
${ }^{3}$ Standard errors are heteroskedasticity-robust. Standard errors adjusted for clusters in id. *, ** and $* * *$ reflect $\mathrm{p}<0.01, \mathrm{p}<0.05$ and $\mathrm{p}<0.10$.

${ }^{4}$ These are the coefficients of country/time effects $\left(\theta_{\mathrm{j}, \mathrm{t}}\right)$ in the random effect hedonic regression model. Percentages are calculated as $100[\operatorname{Exp}(\theta)-1]$.
} 
Table 6 shows the results from applying the same model to the diffused molecules. The Hausman test fails to reject the null hypothesis, so the random effect estimator is consistent and hence used to interpret the price differentials. Coefficient signs are almost the same, and magnitudes remain similar. As it is expected, molecule age variable is significant in random effect specification, indicating that older molecules have lower prices. The estimated price differentials for diffused molecules are reported in the table 7 and figure 2, relative to Germany. The results are the same with previous findings for all countries that price differences are again decreasing at an increasing rate. Germany and the United Kingdom have the highest price differences for all the years, representing less regulated markets with relatively free pricing mechanism.

Figure 1: Quality Adjusted Standard Unit Price Differentials for All Molecules, Normalized to Spain

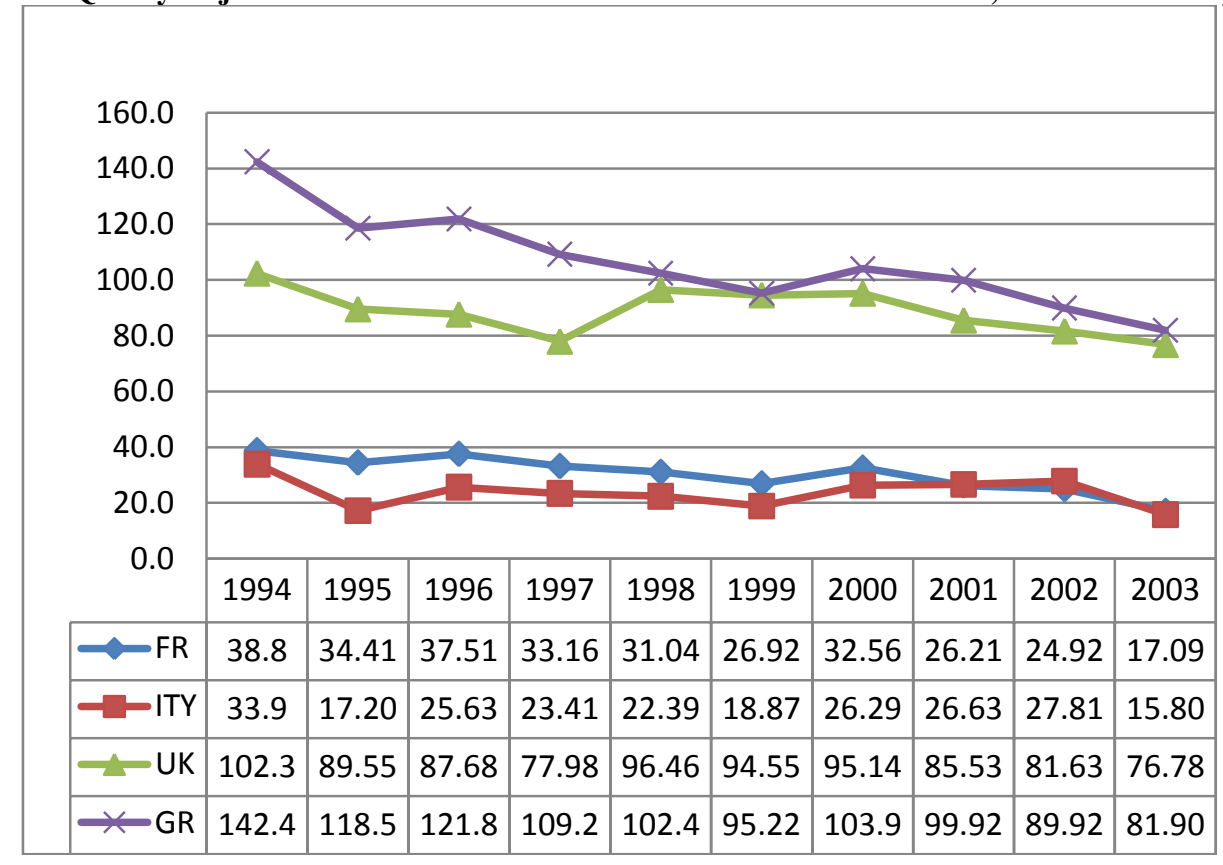

Figure 2: Quality Adjusted Standard Unit Price Differentials for Global Molecules, Normalized to Spain

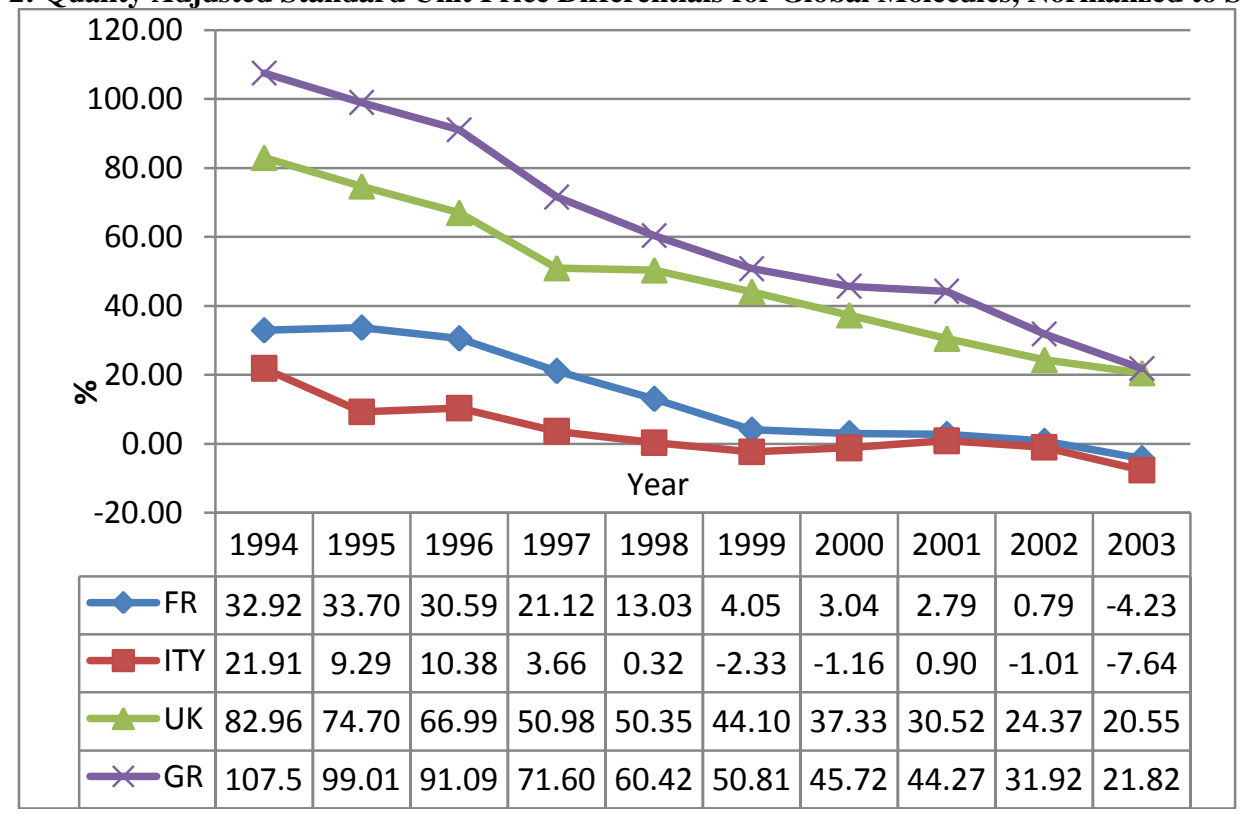




\section{CONCLUSION}

The pharmaceutical industry faces major challenges as the Community shifts toward an integrated single market. To add to the complications on its characteristics, the gradual creation of a single pharmaceutical market poses the European Commission a particular set of problems and confronts it with several dilemmas. The Commission has to deal with the phenomenon on pricing and reimbursement divergence across the members, as well as parallel importing issues, which is under the European Treaty's free movement of goods and competition rules. The rise of parallel importing threatens not just short term profits but the long term investment and innovation potential of the industry. In seeking to harmonize national rules, regulations on pricing and profits controls, the Commission confronts resistance from the member states since all these issues are as a matter of health policy, and thus national competence. Achievement of a single market in pharmaceuticals requires continuing efforts in simplification of legislation and regulation at EU and national levels. In addition to that, the industry doesn't intend to set average "European" prices for their products (European Commission).

This paper finds evidence that price variation across member states exists but it is getting narrower generally, even though the internal market has significant national barriers. We expect to find some price divergence across the member states due to differences in health care systems, pricing and reimbursement regulations. Our results confirm this divergence. France and Italy show similar trends whereas the United Kingdom and Germany indicate closer price differences, with respect to comparable industry characteristics and regulations, relative to Spain. Our results are consistent with existing findings that strictly regulated countries have relatively lower prices (Danzon and Chao 2000b).

Consequently, drug prices indeed diverge across the member states of the European Union, but also it is evident that the price differentials are decreasing over time. It is possible to interpret this as an implicit evidence of gradual achievement of a single pharmaceutical market. Harmonization efforts by the European Commission may ease reducing price differences in the long run but it should not be interpreted as moving toward complete elimination of price differences due to complexities in this industry.

The results of this study are subjected to several limitations. First, our data include only cardiovascular disease drugs in certain therapeutic categories in five countries and only for matching molecules to Spain (price indices), therefore the findings cannot be generalized to all drugs in each country in the European Union. Second, it has been already discussed in the literature that cross country price comparison in pharmaceuticals is very sensitive to produce unbiased results. The validity of empirical results relies on the credibility of the data, the type of conversion factor, the method used, and robustness of the analysis. Our data set extends for only a ten year period and not sufficient enough to find evidence in terms of price differences over time. In our analysis, although we attempt to apply one of the suggested approaches to compare pharmaceutical prices for cross countries, further research is necessary to improve the empirical model and the set of the observed variables. These estimations are likely to be biased by endogeneity, omitted variables and measurement error; thus conclusions are tentative. An extension to the current work will continue to develop a model to find empirical evidence in order to explain how this coordination of divergence in terms of government regulations impacts on price convergence in the European single pharmaceutical market.

\section{ACKNOWLEDGEMENTS}

We gratefully acknowledge financial support for the data set from the Kenneth Oscar Johnson Endowed Professorship Fund at the Kenneth Oscar Johnson School of Business, Hodges University, and the Gaiennie Foundation at the College of Business Administration, University of South Florida. We also appreciate helpful comments from participants in a seminar at the University of South Florida and a session at the 2007 and 2008 Southern Economic Association meetings. 


\section{REFERENCES}

1. Allen, R.G.D. 1975. Index Numbers in the Theory and Practice. Aldine Publishing Company.

2. $\quad$ Berndt, E.R., Bir, A., Busch, S.H., Frank, R.G., and Normand, S.L.T. 2002. "The Medical Treatment of Depression, 1991-1996: Productive Inefficiency, Expected Outcome Variations, and Price Indexes." Journal of Health Economics, 21, pp. 373-96.

3. Berndt, E.R., Cocburn, I.M., Griliches, Z., Keeler, T.E., and Baily, M.N. 1996. "Pharmaceutical Innovations and Market Dynamics: Tracking Effects on Price Indexes for Antidepressant Drugs."

Brookings Papers on Economic Activity. Microeconomics., 1996:1996, pp. 133-99.

4. Berndt, E.R., Griliches, Z., and Rosett, J.G. 1993. "Auditing the Producer Price Index: Micro Evidence From Prescription Pharmaceutical Preparations." Journal of Business \& Economic Statistics, 11:3, pp. 25164.

5. Caves, R.E., Whinston, M.D., Hurwitz, M.A., Pakes, A., and Temin, P. 1991. "Patent Expiration, Entry, and Competition in the U.S. Pharmaceutical." Brookings Papers on Economic Activity. Microeconomics, 1991:1991, pp. 1-66.

6. Danzon, P.M. and Chao, L.W. 2000a. "Cross-National Price Differences for Pharmaceuticals: How Large, and Why?" Journal of Health Economics, 19, pp. 159-95.

7. Danzon, P.M. and Chao, L.W. 2000b. "Does Regulation Drive Out Competition in Pharmaceutical Markets?" Journal of Law and Economics, 43:2, pp. 311-57.

8. Danzon, P.M. and Furukawa, M.F. 2003. "Prices and Availability of Pharmaceuticals: Evidence From Nine Countries." Health Affairs, Web Exclusive.

9. Dickson, M. 1992. "The Pricing of Pharmaceuticals: An International Comparison." Clinical Therapeutics, 14:4, pp. 604-10.

10. Dickson, M. and Jacobzone, S. 2003. "Pharmaceutical Use and Expenditure for Cardiovascular Disease and Stroke: A Study of 12 OECD Countries." OECD Health Working Papers, DELSA/ELSA/WD/HEA (2003)1.

11. Ess, S.M., Schneeweiss, S., and Szucs, T. 2003. "European Healthcare Policies for Controlling Drug Expenditure." Pharmacoeconomics, 21:2, pp. 89-103.

12. European Commission. Free Movement of Pharmaceuticals: What Defines the Prices? http://www.epha.org/a/512. March 2009.

13. European Commission. 1998. The Single Market in Pharmaceuticals. http://europa.eu.int/scadplus/leg/en/lvb/121227.htm. February 2009.

14. $\quad$ European Commission. April 2009. "Enterprise and Industry. Pharmaceutical Industry Policy." (Retrieved from http://ec.europa.eu/enterprise/).

15. Gilles, R. 1940. "International Comparison of Wholesale Prices." The Review of Economic Statistics, 22:3, pp. $150-56$.

16. Guillen, A.M. and Cabiedes, L. 2003. "Reforming Pharmaceutical Policies in the European Union: A "Penguin Effects"?" International Journal of Health Services, 33:1, pp. 1-28.

17. Hausman, J. 1978. "Specification Tests in Econometrics." Econometrica, 46:6, pp. 1251-71.

18. IMS. 2002. "IMS Midas Customized Insights: Data Elements, Measures and Statistics." @ IMS Health Incorporated or Its Affiliates.

19. IMS. 2005. IMS Midas Quantum - Data Elements, Measures and Statistics.

20. Kanavos, P. 2001. Communication of the European Communities, Dg. Enterprise. Overview of Pharmaceutical Pricing and Reimbursement Regulation in Europe. http://www.pharmacos.eudra.orf/F3/g10/docs/synthesis.pdf. April 2005.

21. Kanavos, P. 2002. "Pharmaceutical Regulation in Europe. In: Institute for Research on Public Policy Conference - Toward a National Strategy on Drug Insurance: Challenges and Piorities." Retrieved from: LSE Library-http://www.irpp.org/events/archieve/sep02/kanavos.pdf.

22. Lopez-Casasnovas; Puig-Junoy, J. 2000. "Review of the Literature on Reference Pricing." Health Policy, 54:2, pp. 87-123.

23. Mossialos, E., Mrazek, M., and Wally, T. eds. 2004. Regulating Pharmaceuticals in Europe: Striving for Efficiency, Equity and Quality: Open University Press. European Observatory on Health Systems and Policies Series. 
24. Norris, P. 1998. "The Impact of European Harmonisation on Norwegian Drug Policy." Health Policy, 43, pp. 65-81.

25. Noyce, P.R., Huttin, C., Atella, V., Brenner, G., Haaijer-Ruskamp, F.M., Hedwall, M., and Mechtler, R. 2000. "The Cost of Prescription Medicines to Patients." Health Policy, 52, pp. 129-45.

26. $\quad$ OECD, H.D. 2003. "A Comparative Analysis of 30 Countries."

27. Pammolli, F., Riccaboni, M., and Magazzini, L. 2004. European Competitiveness in Pharmaceuticals.

28. Permanand, G. and Mossialos, E. 2004. "Theorising the Development of the European Union Framework for Pharmaceutical Regulation." LSE Health and Social Care Discussion Paper, Number 13.

29. Redwood, H. 1994. "Public Policy Trends in Drug Pricing and Reimbursement in the European Community." Pharmacoeconomics, 6:1, pp. 1-10.

30. Seget, S. 2003. Pharmaceutical Pricing Strategies: Optimizing Returns Throughout R\&D and Marketing. Reuters Business Insight - Healthcare. 